IRSH 52 (2007), pp. 2 I-34 DOI: I0.10I7/S0020859007003 I00

(C) 2007 Internationaal Instituut voor Sociale Geschiedenis

\title{
The Funny Side of Globalization: Humour and Humanity in Zapatista Framing
}

\author{
THOMASOLESEN
}

Summary: This article argues that the literature on social movements and globalization has not paid sufficient attention to the way in which political actors who act globally try to overcome the social, cultural, and political distances that separate them. It introduces the concept of global framing to give focus to the discursive processes central to such "distance bridging". In particular, it emphasizes how symbols and emotions are crucial in the framing of distance. Empirically, it discusses how the considerable global resonance created by the Zapatistas in Mexico is facilitated by a framing strategy, carried out mainly by the movement's spokesman, Subcomandante Marcos, in which humour, imperfection, and symbols play a decisive role.

\section{INTRODUCTION}

By the mid-r99os globalization was a well-established topic in sociology, but not so in the field of political activism. The first systematic signs of life date only from the second half of the I990s and it took an event, the "Battle in Seattle" in I999, to really spark the growth of a new agenda. ${ }^{\text {T Today, the }}$ field is well out of its infancy, and empirical developments and a steady pace of theoretical refinement have provided newcomers with considerable work to become acquainted with. ${ }^{2}$ All of these works deal implicitly or explicitly with the issue of distance. How, in other words, do individuals and collectives living in different geographical locales and under different social, cultural, and political conditions succeed in

I. For some early works, see Jackie Smith et al. (eds), Transnational Social Movements and Global Politics: Solidarity beyond the State (Syracuse, NY, 1997); Margaret Keck and Kathryn Sikkink, Activists beyond Borders (Ithaca, NY, I998); Donatella della Porta et al. (eds), Social Movements in a Globalizing World (New York, 1999).

2. See for example Sanjeev Khagram, James V. Riker, and Kathryn Sikkink (eds), Restructuring World Politics: Transnational Social Movements, Networks, and Norms (Minneapolis, MN, 2002); Donatella della Porta and Sidney Tarrow (eds), Transnational Protest and Global Activism (Lanham, MD, 2005); Joe Bandy and Jackie Smith (eds), Coalitions across Borders: Transnational Protest and the Neoliberal Order (Lanham, MD, 2005). 
communicating and acting with each other? How, to put it more simply, is the distance between them overcome? These questions are absolutely central to research into activism and globalization, but if we agree with that, then it is surprising how little explicit attention the issue of distance bridging has received in the literature. This article uses Mexico's Zapatistas and the widespread global resonance they have created to illuminate this terrain. ${ }^{3}$ In accordance with the theme of this supplement, I shall analyse how the Zapatistas, and in particular their spokesman, Subcomandante Marcos, have employed a framework of humour, humanity, and imperfection to facilitate global and cross-distance communication.

\section{FRAMING DISTANCE}

Globalization is abstract. In a sociological sense, globalization refers, to borrow Benedict Anderson's phrase, to the creation of imagined communities, ${ }^{4}$ which are social relationships not based on physical co-presence. In a more straightforward manner, it means that we have relationships with people we do not know. Such a view of globalization is a continuation of a well-worn theme in the sociology of modernity. The echo from Durkheim's analysis of the transition from mechanical to organic solidarity, from communities based on physical co-presence to more complex social systems such as the city and the nation, is perhaps especially apparent here. Today social systems are acquiring an additional layer to this complexity: the global level. The idea that globalization constitutes a new phase in, rather than a break with, modernity is present in the work of sociologists such as Anthony Giddens, Ulrich Beck, and Roland Robertson. For Giddens, globalization is central to what he calls the disembedding and post-traditionalization of social relationships; for Beck it ushers in a second modernity and a world risk society without any outer limits; and for Robertson it means the development of a global consciousness. ${ }^{5}$

This increasingly impersonal and complex nature of social relationships is what makes globalization abstract. For actors wishing, for one reason or another, to communicate with other actors across social, cultural, political, and geographical distances, it represents a huge challenge. How, in other

3. The official name of the Zapatistas is the EZLN (Ejército Zapatista de Liberación Nacional/ Zapatista Army of National Liberation).

4. Benedict Anderson, Imagined Communities: Reflections on the Origin and Spread of Nationalism (London, 1983 ).

5. Roland Robertson, Globalization: Social Theory and Global Culture (London, 1992); Anthony Giddens, "Living in a Post-Traditional Society", in Ulrich Beck, Anthony Giddens, and Scott Lash, Reflexive Modernization: Politics, Tradition, and Aesthetics in the Modern Social Order (Cambridge, 1994), pp. 56-109; Ulrich Beck, "The Cosmopolitan Perspective: Sociology of the Second Age of Modernity", British Journal of Sociology, 5 I (2000), pp. 79-105. 
words, can I succeed in making my daily life intelligible and of concern to people living under conditions widely different from mine? That is indeed a big question, theoretically as well as practically. It is one that can be approached in a number of ways. One would be to consider the structural conditions on the world political stage that enable cross-distance communication. Another would be to look at global media infrastructures. Here, in line with the theme of this volume, I will consider only the discursive challenges in cross-distance communication, the guiding question being: what discursive components can be expected to facilitate communication across distance?

Framing theory, which has stimulated an enormously wide range of studies within social movement research, offers the analyst a potent set of theoretical tools for thinking about distance bridging, ${ }^{6}$ although so far it has been applied mainly to national activism. What makes it suitable for the study of global activism too is that it is concerned essentially with distance bridging. In their seminal i 986 article, Snow and his colleagues introduced the concepts of frame bridging, frame extension, and frame amplification, which have since become staples of framing research. ${ }^{7}$ These concepts clearly suggest that framing tries to create resonance across social, cultural, and political distance, to forge a connection with others in the public space. Framing, to be more precise, is an attempt by a collective to present a given interpretation of reality to an audience and to convince that audience of the accuracy and legitimacy of that interpretation. The ultimate aim is to generate support, material and moral, for the framer's claims and, through that, to increase his chances of achieving his aim.

Whether it takes place in a local, national, or global context, creating frame resonance is highly complex. Framing in a global space faces additional problems for the simple reason that social, cultural, and political distances and differences are more pronounced there. As already stated, framing theory provides a solid foundation for addressing such questions, but a genuine theory of global framing requires us to be more theoretically explicit about the special problems that confront global framers. ${ }^{8}$ What I want to do here is draw attention to the importance of symbols and

6. For reviews of the framing perspective, see John A. Noakes and Hank Johnston, "Frames of Protest: A Road Map to a Perspective", in idem (eds), Frames of Protest: Social Movements and the Framing Perspective (Lanham, MD, 2005), pp. I-29; Robert D. Benford and David A. Snow, "Framing Processes and Social Movements: An Overview and Assessment", Annual Review of Sociology, 26 (2000), pp. 6i i -639.

7. David A. Snow et al., "Frame Alignment Processes, Micromobilization, and Movement Participation", American Sociological Review, 5 I (1986), pp. 464-48 r. For a recent collection of articles on framing and protest, see Michiel Baud and Rosanne Rutten (eds) "Popular Intellectuals and Social Movements: Framing Protest in Asia, Africa, and Latin America", International Review of Social History, Supplement I 2 (Cambridge, 2004).

8. Tellingly, the global aspect is almost completely absent in a recent volume on frames and activism: Noakes and Johnston, Frames of Protest. 
emotions, which I contend contain universals that facilitate communication across distance. Humour can be thought of as both symbolic and emotional. At the end of their 2000 review article, Benford and Snow note that emotions are conspicuously absent in framing theory. ${ }^{9}$ Among more culturally oriented scholars, in contrast, growing attention has been paid to emotions in recent years. ${ }^{10}$ In what follows I shall draw on both positions to sketch a theory of global framing.

Although framing theory made its entry as a social constructionist corrective to the dominance of resource-mobilization and politicalopportunity theory in social movement studies, it has retained the emphasis of those approaches on rational and strategic action. ${ }^{\text {II }}$ Framing is a calculated attempt to attract sympathy and support. Emotions are immanent in many of the theory's arguments, but, as pointed out in an important critique by Jeff Goodwin and James Jasper, they tend to be overshadowed by strategy. ${ }^{12}$ William Gamson, another leading framing scholar, perhaps comes closest to giving emotions a proper place. Gamson argues that all frames contain an injustice frame, his point being that people are essentially driven to activism by feelings such as anger and frustration. ${ }^{13}$ Cultural scholars such as Jeff Goodwin, James Jasper, and Francesca Polletta go a step further. From their perspective, activism is creative and morally driven. Importantly, they are eager to stress that there is no contradiction between emotions and strategic thinking. ${ }^{14}$ Along the same lines, elsewhere I have used Jasper and Poulsen's concept of moral shocks to explain the mobilization of transnational campaigns. ${ }^{\text {Is }}$ Moral

9. Benford and Snow, "Framing Processes and Social Movements".

ı. See for example Jeff Goodwin et al. (eds), Passionate Politics: Emotions and Social Movements (Chicago, IL, 200I).

I I. Resource mobilization and political opportunities emerged as reactions to so-called collective-behaviour theories of activism, which tended to view activism as irrational and as a response to social strain and breakdown. Resource-mobilization theorists emphasize the rational and strategic behaviour of protesters and the crucial role of organization and resources in protest. Political-opportunity theorists share the rationality and strategy component, but direct attention to the way the political system shapes activism. For some of the founding texts of resourcemobilization and political-opportunity theory respectively, see John D. McCarthy and Mayer N. Zald, "Resource Mobilization and Social Movements: A Partial Theory", American Journal of Sociology, 82 (1977), pp. I2 I2-I24I; Charles Tilly, From Mobilization to Revolution (Reading, MA, I978).

I 2. Jeff Goodwin and James Jasper, "Caught in a Winding, Snarling Vine: The Structural Bias of Political Process Theory”, Sociological Forum, I4 (1999), pp. 27-54. For a discussion of the reasons behind the absence of emotions in sociology and political science, see Ron Aminzade and Doug McAdam, "Emotions and Contentious Politics", in Ronald R. Aminzade et al., Silence and Voice in the Study of Contentious Politics (Cambridge, 200I), pp. 14-50.

I3. William Gamson, "Constructing Social Protest", in Hank Johnston and Bert Klandermans (eds), Social Movements and Culture (Minneapolis, MN, 1995), pp. 85-106.

I4. Jeff Goodwin et al., "Introduction: Why Emotions Matter", in Goodwin et al., Passionate Politics, pp. I-24, 9.

I 5. James M. Jasper and Jane D. Poulsen, "Recruiting Strangers and Friends: Moral Shocks and 
shocks, I have argued, help bridge distance because they address universal conceptions of human dignity and suffering. ${ }^{16}$ What I want to address here is not so much the role of indignation in global framing, but something more subtle and less aggressive: humour.

Humour is rarely discussed by cultural scholars. I would contend, however, that humour needs to be analysed in an emotional framework. Any communication based on humour requires an emotional readiness and openness on the part of all parties involved. Humour is symbolic, especially in a political context when it tries to relay a broader message that cannot be deduced directly from the humorous point itself. In that sense, humour serves to condense meaning, ${ }^{17}$ and condensation of meaning through the use of symbols is a way of making framing and communication more efficient. But that can be done only by building on meanings which are already part of people's stock of cultural and historical information. The efficient symbol, then, is one that draws on universal or almost universal experience and values. In the words of framing theorists, efficient communication must have cultural resonance. ${ }^{18}$

In an early treatment of globalization, Malcolm Waters argued that symbols are globalizing. ${ }^{19}$ Because of the ability to package meaning efficiently around universals, symbols are particularly useful when it comes to framing activities that seek to transcend social, cultural, and political distances. Put differently, symbols can help overcome what was referred to at the beginning of this section as the abstractness of globalization. Of course, the use of symbols in frames can take various forms. Humour as a symbol in framing across distance can be powerful because it often evokes human frailties and imperfections that are universally recognizable. When a communicator uses humour in that way he opens himself to the recipient of his message by implicitly saying: "I am only human just like you". Humour can therefore function to open doors to more explicit and "serious" communication about social and

Social Networks in Animal Rights and Anti-Nuclear Protests”, Social Problems, 42 (1995), pp. 493-5I 2.

I6. Thomas Olesen, “'In the Court of Public Opinion': Transnational Problem Construction in the HIV/AIDS Medicine Access Campaign, 1998-200I”, International Sociology, 2 I (2006), pp. $5-30$.

17. Cobb and Elder define a symbol as "any object used by human beings to index meanings that are not inherent in, nor discernible from, the object itself”. See Charles D. Elder and Roger W. Cobb, The Political Uses of Symbols (New York, I983).

I 8. See for example Jiping Zuo and Robert D. Benford, "Mobilization Processes and the 1989 Chinese Democracy Movement", Sociological Quarterly, 36 (1995), pp. I3I-I56; Sidney Tarrow, "Mentalities, Political Cultures, and Collective Action Frames: Constructing Meanings through Action", in Aldon D. Morris and Carol McClurg Mueller (eds), Frontiers in Social Movement Theory (New Haven, CT, I992), pp. 174-202.

19. Malcolm Waters, Globalization (London, 1995). 
political issues, but used in political cross-distance framing it seldom stands alone, usually forming part of a broader scheme of communication.

\section{METHODOLOGY AND STRUCTURE}

I would emphasize from the outset what I do not intend to do in this analysis of humour in the Zapatistas' cross-distance framing. By focusing on humour, humanity, and imperfection I do not imply that they are what explain the global resonance of the Zapatistas. My analysis is mainly descriptive and exploratory in illuminating one component in the complex Zapatista frame. ${ }^{20}$ In that, it is suggestive too of future directions for analysis of the Zapatistas, as well as of globalization generally. ${ }^{2 \mathrm{I}}$

The data source for this analysis is Zapatista documents. The Zapatistas have been very productive in disseminating information and political analyses, which reflects the Zapatista self-conception as an army of words rather than weapons. ${ }^{22}$ The documents have various authors, but in general the communicative and framing work of the movement has been in the hands of Subcomandante Marcos. Marcos is usually referred to as a spokesman, but is in effect a key leader of the movement. In the following I draw mainly on Marcos's writings, where primarily we encounter humour. I have chosen to quote at some length in the analysis. That, I believe, is necessary in an analysis of framing where a central aim is to convey to the reader a sense of how the actor in question communicates and frames his messages.

As I have said, the Zapatistas have been prolific in their communicative production, so the analysis below can do no more than dip into the body of their texts to extract a few selected examples. I have chosen three that in their different ways illuminate how Marcos's frames have used humour and symbols. The examples, which form the structure of the following discussion, concern first, the origins of the Zapatista movement in the early I980s, second the relationship between the Zapatistas and global solidarity activism, and then the most recent major Zapatista initiative, the "Other Campaign". I will begin my analysis, however, with a brief introduction to the framing used by the Zapatistas.

20. For a more comprehensive analysis of what I call transnational framing in relation to the Zapatistas, see Thomas Olesen, International Zapatismo: The Construction of Solidarity in the Age of Globalization (London, 2005).

2I. I am by no means the first to stress the role of humour and humanity in Zapatista framing; see for example Nicholas Higgins, "The Zapatista Uprising and the Poetics of Cultural Resistance", Alternatives, 25 (2000), pp. 359-374.

22. The most extensive collection of English translations of Marcos's writings is thus aptly titled Our Word Is Our Weapon: Juana Ponce de León (ed.), Our Word is Our Weapon: Selected Writings, Subcomandante Marcos (London, 200I). 


\section{HUMOUR AND HUMANITY IN ZAPATISTA FRAMING}

A salient feature of the Zapatistas has been their ability to generate resonance globally since their uprising in $1994 .{ }^{23}$ As I have analysed more extensively elsewhere, ${ }^{24}$ that resonance is the result of a successful framing strategy, which contains numerous dimensions. But there is one feature that seems to be present in all variations of their framing: its humanity. In almost every intervention the Zapatistas stress their own imperfections and mistakes and portray their protest as an open question, a process rather than something with a clear strategy and final goal. Humour plays a central part in their imperfection frame.

In his communiqués, Subcomandante Marcos uses two layers of framing: there is a "serious" level which is about political analysis and strategy, but it is constantly accompanied by meta-reflections about the Zapatistas' thought processes, their doubts, their everyday experiences. This second layer is saturated with humour and gives a very human impression, something almost entirely absent in the more self-important and pompous revolutionary movements of the I960s, I970s, and I980s; a tradition from which the Zapatistas consider themselves to have departed in many important respects. ${ }^{25}$ Their humanistic self-portrayal laced with humour has therefore facilitated the global resonance of the Zapatistas' framing activities. By presenting themselves as ordinary flawed and troubled human beings with no predetermined answers to every question, they are able to speak to a much broader audience than would otherwise have been prepared to listen. The "openness" of the movement, in other words, allows a wide variety of people and groups to find points of resonance in the Zapatista frame.

\section{Burnt-out light bulbs}

The Zapatista organization was formed in the early i 980 s by a group of urban intellectuals from Mexico City. As they began to come into contact with the indigenous communities of Chiapas, they were gradually forced to reconsider the ideological and theoretical baggage of the Marxism and revolution they had brought with them. This "clash" between the indigenous way of thinking and the urban intellectuals is a central theme in Zapatista self-mythology. ${ }^{26}$ Their formative story has been told on many occasions by Marcos as a way of elucidating the political ideas of the Zapatistas based on dialogue and democracy, the centrality of which is

23. Olesen, International Zapatismo.

24. Ibid.

25. See for example the interview with Marcos in Gabriel Garcia Márquez and Roberto Pombo, "Habla Marcos", Revista Cambio, 28 March 200 I.

26. Olesen, International Zapatismo, pp. I I3-1 i6. 
ascribed to the influence of those indigenous communities and their century-long experience of social and political protest and organization. Below, I shall discuss how this self-conception is linked to their experiences following the uprising in 1994, when the Zapatistas entered into dialogue with civil society.

Using irony and humour Marcos recently described the founders of the Zapatistas as:

[...] a group of "illuminati" who came from the city in order to "liberate" the exploited and who looked, when confronted with the reality of the indigenous communities, more like burnt out light bulbs than "illuminati". How long did it take us to realize that we had to learn to listen, and, afterwards, to speak? I'm not sure, not a few moons have passed now, but I calculate some two years at least. Meaning that what had been a classic revolutionary guerrilla war in 1984 (armed uprising of the masses, the taking of power, the establishment of socialism from above, many statues and names of heroes and martyrs everywhere, purges, etcetera, in sum, a perfect world), by 1986 was already an armed group, overwhelmingly indigenous, listening attentively and barely babbling its first words with a new teacher: the Indian peoples. ${ }^{27}$

The intention with stories such as that is to portray the Zapatistas as imperfect, or, put differently, as human, another theme I shall touch on later. Human beings, in their ideas, constantly stumble and take wrong turns. Frailty and imperfection are often the basis for humour, so almost by necessity humour comes to play a central part in the Zapatistas' selfunderstanding. The essence of life is to learn from experience, a learning which takes place essentially through dialogue with others and is well captured in the Zapatista catchphrase, "asking we walk" (preguntando caminamos).

Social and political change, then, is not just about some distant goal, but just as much about the method and the way to get there. Understanding that sets the Zapatistas apart from the more traditional revolutionary groups of Latin America in both past and present, which have often proceeded from a ready-made theory of where to go and how to get there. Speaking about their own experience and aims in humorous and human terms serves to create a point of reference for people all over the world. Everyone is familiar with the types of mistakes and doubts that the Zapatistas have always faced. We all know, from our daily lives, that existence cannot be "planned" and that the best results are often achieved by cooperation and discussion with others. The dialogical element also includes, inviting people to participate in social and political protest with the Zapatistas, rather than following a predefined path carved out by a revolutionary avant-garde.

27. Subcomandante Marcos, "Chiapas, the Thirteenth Stele: Part Two, A Death”, 25 July 2003, available at www.zmag.org/content/showarticle.cfm?ItemID=3957 (last accessed 29 May 2007). 


\section{A pink stiletto beel, size $6 \frac{I}{2}$, without its mate}

In a $200 \mathrm{I}$ interview with Carlos Monsivaís and Hermann Bellinghausen, Marcos stated that the Zapatistas were prepared for I January I994, when they staged their uprising in Chiapas, but not for 2 January. ${ }^{28}$ What he meant was that the reactions to the uprising were quite unexpected. The Zapatistas were met by what Marcos later referred to as a Zapatismo civil. ${ }^{29}$ It is a central theme in the Zapatistas' self-mythology, how it was that their armed uprising generated a huge resonance from civil society within and outside Mexico, and that it ended up shaping the organization and its strategies in important ways. Indeed, in the story of the origins of the organization discussed above, the emphasis in the meeting between the Zapatistas and Zapatismo civil is on dialogue, listening, and learning. The interest of external actors in the uprising provided the Zapatistas with a much needed spotlight on a situation in which the Mexican government and army were considering whether to opt for a military "solution" or to negotiate. After two weeks of fighting in early January the parties eventually started a dialogue. Since that early January no shots have been fired, although Chiapas remains heavily militarized and the Zapatistas still bear arms there.

The Zapatistas have benefited greatly from this external attention. Solidarity has come in many shapes: for example, NGO development projects, money, materials, and volunteers living as peace monitors in Zapatista communities. But solidarity activists too have benefited because for many the Zapatista uprising and its political theory acted as a motivator and inspiration at a time when the Left was trying to redefine itself in the wake of the end of the Cold War. In physical terms, solidarity activists could "meet" the Zapatistas in the so-called Aguascalientes in Zapatista territory. The Aguascalientes was the scene of several large encounters between the Zapatistas and Mexican and global solidarity activists during the I990s. In 2003, in a surprising move, the Zapatistas announced the dismantling of the Aguascalientes and, with it, an attempt to redefine the relationship between Zapatista communities and solidarity activists.

In a communiqué from 2003 Marcos acknowledges the huge importance of solidarity for the Zapatistas, but he laments the fact that the relationship is often based not on mutual respect but on pity and charity. Quoting from a letter he wrote in 1994, Marcos illustrates the point:

From what our people received in benefit [...] I saved an example of "humanitarian aid" for the chiapaneco indigenous, which arrived a few weeks ago: a pink stiletto heel, imported, size $6 \frac{1}{2}[\ldots]$ without its mate. I always carry it in my backpack in order to remind myself, in the midst of interviews, photo

28. Carlos Monsivaís and Hermann Bellinghausen, "Marcos a Fox: Queremos garantías; no nos tragamos eso de que todo cambió", La Jornada, 8 January $200 \mathrm{I}$.

29. Yvon Le Bot, El sueño zapatista (Barcelona, I997), p. 306. 
reports and attractive sexual propositions, what we are to the country after the first of January: a Cinderella. [...] These good people who, sincerely, send us a pink stiletto heel, size $6 \frac{1}{2}$, imported, without its mate [...] thinking that, poor as we are, we'll accept anything, charity and alms. How can we tell all those good people that no, we no longer want to continue living Mexico's shame. In that part that has to be prettied up so it doesn't make the rest look ugly. No, we don't want to go on living like that. ${ }^{30}$

Marcos then goes on to assess how things have developed since then:

That was in April of 1994. Then we thought it was a question of time, that the people were going to understand that the zapatista indigenous were dignified, and they weren't looking for alms, but for respect. The other pink heel never arrived, and the pair remained incomplete, and piling up in the "Aguascalientes" were useless computers, expired medicines, extravagant (for us) clothes, which couldn't even be used for plays [...] and, yes, shoes without their mate. And things like that continue to arrive, as if those people were saying "poor little things, they're very needy. I'm sure anything would do for them, and this is in my way".

And that's not all. There is a more sophisticated charity. It's the one that a few NGOs and international agencies practice. It consists, broadly speaking, in their deciding what the communities need, and, without even consulting them, imposing not just specific projects, but also the times and means of their implementation. Imagine the desperation of a community that needs drinkable water and they're saddled with a library. The one that requires a school for the children, and they give them a course on herbs. ${ }^{31}$

Marcos is tackling a very delicate subject here through the use of humour and symbols. The balance needing to be struck is to define the Zapatista conception of solidarity without alienating and offending solidarity activists. The lone pink stiletto heel is a powerful and humorous symbol of the dark side of solidarity. A shoe without its mate is a symbol that can be widely understood. And sending a stiletto heel to a place where there are few pavements further underlines the well-intentioned absurdity of this act of solidarity. The stiletto heel becomes a symbol of a kind of solidarity where the sender does not think to ask the recipient what he really needs. For the Zapatistas, that is not solidarity but pity and charity, a sign of a lack of respect and understanding on the part of the giver.

The stiletto heel sets the stage for a more serious and damning critique of solidarity activities that are not the result of a true dialogue with Zapatista communities. The parable works well because it allows the solidarity activist reader of the message to exempt himself easily from the critique. Who in their right mind, the reader giggles, would send a lone stiletto heel to Chiapas? But when Marcos changes gear and speaks about useless materials and misguided development projects it is likely that the

30. Marcos, "Chiapas, the Thirteenth Stele".

31. Ibid. 
solidarity activist will at least have encountered similar experiences, either through observation or through his own efforts. The stiletto-heel parable, in other words, "lures" the reader into accepting Marcos's broader and more serious point.

\section{A penguin in the Lacandon Forest}

In the summer of 2005 , after a prolonged period without much outward activity, the Zapatistas relaunched themselves with the so-called Sixth Declaration of the Lacandon Forest. In that document, the organization presented wide-ranging new initiatives, in particular the "Other Campaign”. The Other Campaign, which saw Zapatista delegates tour Mexico for several months, was intended to be an alternative and parallel campaign to the Mexican presidential race in 2006, an anti-neoliberal campaign, as the Zapatistas saw it, for the most marginalized and impoverished sectors of the Mexican population. The declaration gave rise to a variety of critical responses and comments. Later that summer, Subcomandante Marcos responded at length to the critiques directed against the Sixth Declaration, which had clearly not been written by Subcomandante Marcos himself but was signed simply by "the Zapatista military leadership".

The document starts with Marcos noting that there is a penguin in the Zapatista headquarters. Without going further into this rather strange observation, promising only to return to the penguin later in the document, he begins a series of sharp-edged refutations and commentaries regarding the Sixth Declaration and its critics. In the final section, keeping his promise, Marcos changes tone and explains the story of the penguin. $\mathrm{He}$ recounts how, in the process of dismantling a camp in the Lacandon Forest, the soldiers were eating the chickens that had been raised in the camp, but:

When only one remained, on the precise day of departure, what happened happened. [...]. The last chicken began walking upright, perhaps trying to be mistaken for one of us and to pass unnoticed with that posture. I don't know much about zoology, but it does not appear that the anatomical makeup of chickens is made for walking upright, so, with the swaying produced by the effort of keeping itself upright, the chicken was teetering back and forth, without being able to come up with a precise course. It was then that someone said "it looks like a penguin". The incident provoked laughter which resulted in sympathy. The chicken did, it's true, look like a penguin, it was only missing the white bib. The fact is that the jokes ended up preventing the "penguin" from meeting the same fate as its compañeros from the farm..$^{22}$

The penguin, saved by laughter and sympathy, returned with the soldiers, including Marcos himself, to the Zapatistas' headquarters. Here, www.zmag.org/content/showarticle.cfm?ItemID $=8398$ (last accessed 29 May 2007). 
he says, it quickly adapted to the routines of the insurgents' life in the forest. In fact, it soon became clear that it was considering itself one of them:

We hadn't realized how far it had gone until one afternoon when it refused to eat in the corner it had been assigned, and it went over to the wooden table. Penguin made a racket, more chicken-like than penguin-like, until we understood that it wanted to eat with us. [...] The insurgent captain in charge had told me that the chicken, I mean penguin, did not like to be alone at night, perhaps because it feared that the possums might confuse it with a chicken, and it protested until someone took it to their tarp.

Then, after the comical account of the penguin's transformation, Marcos reveals the story's point:

Do you know what? It occurs to me now that we are like Penguin, trying very hard to be erect and to make ourselves a place in Mexico, in Latin America, in the World. Just as the trip we are about to take is not in our anatomy, we shall certainly go about swaying, unsteady and stupidly, provoking laughter and jokes. Although perhaps, also like Penguin, we might provoke some sympathy, and someone might, generously, protect us and help us, walking with us, to do what every man, woman or penguin should do, that is, to always try to be better in the only way possible, by struggling. ${ }^{33}$

The story of the penguin, as this paragraph shows, is a story about the heroics of trying, despite unfavourable odds, imperfection, and insecurity. The penguin tried to adapt to changing circumstances by doing something that is not natural to it, but it succeeded out of desperation and necessity. That, as Marcos indicates, is the essence of struggling. Struggling in this perspective is about more than securing a share of the resources, about more than placing things on the agenda. It is rather a way of life, a choice driven, as the cultural scholars introduced above would have it, by moral and emotions. ${ }^{34}$ Using humour, as Marcos does in the penguin story, serves to place the point precisely in an emotional and moral universe. The penguin is an effective symbol to accomplish that goal. We all know what a chicken and a penguin look like and it does not take much imagination to visualize the scene and the comical difficulty the chicken would encounter in trying to stand upright.

Yet even if the story is humorous, it has a deeply serious and even rather poignant undercurrent. The chicken's attempt to stand upright and transform itself into something which it is not is, in fact, done to defend itself against otherwise inevitable mortal danger. Again, it is hard not to feel sympathy and pity. To see someone humiliate or transform himself in order to avoid an imminent threat is a heart-wrenching sight for all

33. Ibid.

34. This view is also expressed in the Zapatistas' widespread use of the concept of dignity; see for example Olesen, International Zapatismo, pp. I19-I 20. 
humans. At the same time such acts also call forth our admiration. Struggling against the odds is typically seen as heroic. By fusing the pitiful and the heroic in a symbolic and humorous parable Marcos attempts to provoke sympathy and support from external actors. Prefacing the story of the penguin, Marcos speculates about the possible violence that the Zapatistas will encounter when they set out on their tour of Mexico. The Zapatistas, in other words, will need the support and understanding of people and groups in Mexico and abroad as they embark on the Other Campaign.

\section{CONCLUSION}

This article has zoomed in on humour and symbols in Zapatista framing, arguing that the use of humour and symbols facilitated the global resonance that the Zapatista uprising has generated since i994. It has done so on the basis of theories about framing, emotions, and globalization and through three short "stories" told by Subcomandante Marcos. In the first story, Marcos recounts how the Zapatistas were formed in the early I 980 s as a result of a meeting between a group of urban intellectuals and the indigenous communities in Chiapas. The story serves as a democratic invitation to activists to participate with the Zapatistas, rather than simply follow their lead. In the second story, Marcos speaks about the nature of global solidarity with the Zapatistas. While recognizing the benefits of it, he criticizes some of it for not being based on mutuality and respect for the Zapatistas. In the third story, Marcos tries to evoke the sympathy and support of external activists for the impending Other Campaign. Fearing violent repression as the Zapatistas plan to embark on a political tour of Mexico, he used the parable of a chicken that transforms itself to walk upright like a penguin in an attempt to avoid being slaughtered. The Zapatistas, says Marcos, are like this penguin in the Lacandon Forest, trying to stand upright in a difficult situation and needing support and sympathy to survive.

In this article I have portrayed a largely positive and successful case of global framing. In conclusion, however, I think it is important to ask some more searching questions about the real potential and reach of global framing.

First of all, framing is essentially a relation between an author and an audience, and the author has a specific audience in mind. Communication can hardly be effective and meaningful unless it is formulated with a recipient in mind. But by tailoring his communication the frame's author excludes others. Seen like that, global framing is indeed often a rather exclusive affair. In the case of the Zapatistas it is clear that when Marcos speaks he addresses a well-educated urban middle class in Europe and the US, where his extensive use of a literary style and humorous parables 
seems to go down particularly well. The upshot of course is that the frame risks "missing" workers, for example, or immigrants, people on social security; people, in other words, who are probably "closer" to the Zapatistas in terms of their social and political precariousness.

But in the second place, this image of exclusion can be reversed too. To continue what has just been said, it is important to stress that those who "listen" to groups like the Zapatistas tend to come from the well-educated middle classes in well-off parts of the world. Given the stiff competition for attention in the global public sphere, there is a risk that those who find an ear in Europe and the USA are those who in one way or another can "speak the language" of those audiences, which can create a kind of hierarchy between the "well-educated oppressed" and the "poorly educated oppressed" from which some voices will inevitably be excluded.

Third, it is evident that when speaking of competition, that has increased since 9/I I. Messages issued by terrorist groups, and particularly al-Qaeda, generate routine attention from media, politicians, and the public. The politics of fear that such groups stand for and thrive on is the mirror opposite of the humour and humanity in the Zapatista frame. Terrorist frames are absolutely devoid of humour and instead speak a language of threat and violence. Sadly it seems that the politics of fear and violence automatically create a much larger audience than those of humour and humanity.

We are left to wonder whether the Zapatista frame of humour and humanity "only" reflected and derived its resonance from the more cosmopolitan, optimistic, and post-Cold War I990s, and whether 9/I i has returned us to the security imperative characteristic of the Cold War period. It is certainly no cheerful conclusion to draw, but a sober look at the world of today does suggest that the voices of war and violence, belonging equally to the terrorists and those engaged in the "war on terror", are occupying the centre of the global public sphere, pushing the voices of humour and humanity to the periphery. Those voices need to be heard now more than ever. We, as academics, have a special obligation to try to give them a place in public debate. 